\title{
Effects of Ca Antagonists, Nifedipine, Niludipine and Verapamil, on Endocrine Function of the Pancreas
}

\author{
Akira Ohneda, Takashi Kobayashi and Jiro Nihei \\ The Third Department of Internal Medicine, Tohoku University \\ School of Medicine, Sendai 980
}

\begin{abstract}
Ohneda, A., Kobayashi, T. and Nihei, J. Effects of Ca Antagonists, Nifedipine, Niludipine and Verapamil, on Endocrine Function of the Pancreas. Tohoku J. exp. Med., 1983, 140 (2), 153-159 — To study the effects of two Ca antagonists, nifedipine and niludipine, on insulin and glucagon secretion, experiments were performed using an in situ local circulation of the canine pancreas. The test drugs were injected into the pancreatic artery in three graded doses $(5,10$ and 100 nmoles $/ \mathrm{kg}$ ) during arginine infusion, and blood samples were taken from the pancreatic vein. Verapamil, 10, 100 and 1,000 nmoles/kg, administered in the same way, was used as a control drug. Nifedipine, 5 to $100 \mathrm{nmoles} / \mathrm{kg}$, decreased plasma insulin (IRI) and increased plasma glucagon (IRG) in the pancreatic vein, but caused no marked changes of blood glucose levels in five dogs. Niludipine, 5 to 100 nmoles $/ \mathrm{kg}$, injected into the pancreatic artery of 5 dogs, did not change blood glucose levels, but decreased slightly plasma IRI in the pancreatic vein and increased plasma IRG. Verapamil administered to 5 dogs caused no remarkable change of blood glucose or plasma IRG but decreased plasma IRI slightly. The maximum secretion of insulin was significantly lowered by nifedipine and niludipine, and that of pancreatic glucagon markedly increased by niludipine. The experiments revealed that $\mathrm{Ca}$ antagonists inhibit insulin secretion, and increase glucagon, and proved that calcium plays an important role in the A cell function of the pancreas. ____ plasma glucagon; plasma insulin; blood glucose; pancreatic vein; arginine infusion
\end{abstract}

Calcium is known to play an important role in the process of secretion of various peptide hormones (Rubin 1970). However, consistent results have not been obtained with respect to the involvement of calcium in secretion of pancreatic glucagon (Leclercq-Meyer et al. 1973; Kuzuya et al. 1974; Ashby and Speake 1975; Iversen and Hermansen 1977). According to our results a rise in serum calcium inhibits the secretion of pancreatic glucagon, but accelerates secretion of insulin (Ohneda et al. 1974). To elucidate the effects of calcium on the endocrine function of the pancreas, experimental studies were carried out in dogs using two Ca antagonists, nifedipine and niludipine, and verapamil as the control drug.

\section{Materials AND Methods}

Animals and preparation. An in situ local circulation of the pancreas was prepared in 19 healthy mongrel dogs by a method described elsewhere (Ohneda et al. 1977). The

Received for publication, September 13, 1982. 
abdomen was opened under pentobarbital anesthesia and a glass $\mathbf{T}$ cannula connected with a teflon tubing was placed into the superior pancreaticoduodenal artery. A plastic needle was inserted into the pancreatic vein and fixed to the duodenum. Furthermore, plastic needles were inserted into both femoral arteries for blood sampling and measurement of blood pressure.

Experimental procedure. After the operation, physiological saline solution, $2.0 \mathrm{ml} / \mathrm{min}$, was injected into the pancreatic artery. About $1 \mathrm{hr}$ later, the experiments started. Two baseline samples were taken at an interval of $10 \mathrm{~min}$, and $1 \%$ arginine solution was injected into the pancreatic artery at a rate of $2.0 \mathrm{ml} / \mathrm{min}$. Twenty min after arginine infusion, nifedipine or niludipine, 5, 10 and $100 \mathrm{nmoles} / \mathrm{kg}$, was administered during $10 \mathrm{~min}$ at 40-min intervals. Verapamil was given in doses of 10,100 and $1,000 \mathrm{nmoles} / \mathrm{kg}$ for comparison. As a control experiment, arginine only was administered into the pancreatic artery for $140 \mathrm{~min}$ in five dogs.

Blood sampling and analyses. Blood samples, $4.0 \mathrm{ml}$, were collected from the pancreatic vein for insulin and glucagon measurements in a heparinized syringe, poured into a test tube containing 1,000 U Trasylol (Bayer Yakuhin, Tokyo) and cooled. After the completion of the experiments, the blood was centrifuged to separate plasma and kept at $-20^{\circ} \mathrm{C}$ until determination. Blood glucose was measured by the glucose oxidase method (Teller 1956): Plasma insulin (IRI) was determined by the Morgan-Lazarow method (Morgan and Lazarow 1963). Plasma glucagon (IRG) was measured by radioimmunoassay, using a specific antiserum G-21, as reported previously (Ohneda et al. 1975). A catheter inserted into the femoral artery was connected directly with a mercury sphygnomanometer for blood pressure measurement.

Data and statistical analyses. Results were expressed as mean士s.E. For statistical analyses, Student's $t$-test was performed.

\section{Results}

\section{Nifedipine}

The influence of nifedipine on blood glucose, plasma IRI and plasma IRG is shown in Fig. 1. Nifedipine in any dose applied did not affect blood glucose. Plasma IRI decreased from $270 \pm 43$ to $182 \pm 34 \mu \mathrm{U} / \mathrm{ml} 15$ min after injection of 5 nmoles $/ \mathrm{kg}(1.75 \mu \mathrm{g} / \mathrm{kg})$, from $222 \pm 35$ to $182 \pm 26 \mu \mathrm{U} / \mathrm{ml} 3$ min after administration of $10 \mathrm{nmoles} / \mathrm{kg}(3.5 \mu \mathrm{g} \mathrm{kg})$, and tended to decrease from $230 \pm 38$ to $187 \pm 29 \mu \mathrm{U} /$ $\mathrm{ml} 10 \mathrm{~min}$ after application of $100 \mathrm{nmoles} / \mathrm{kg}(35 \mu \mathrm{g} / \mathrm{kg})$. Plasma IRI levels did not differ significantly from those in control experiments. Plasma IRG increased from $351 \pm 68$ to $624 \pm 139 \mathrm{pg} / \mathrm{ml} 20 \mathrm{~min}$ after injection of 5 nmoles $/ \mathrm{kg}$ nifedipine, from $644 \pm 135$ to $787 \pm 219 \mathrm{pg} / \mathrm{ml} 6 \mathrm{~min}$ after administration of $10 \mathrm{nmoles} / \mathrm{kg}$ and from $461 \pm 103$ to $975 \pm 240 \mathrm{pg} / \mathrm{ml} 15 \mathrm{~min}$ after application of 100 nmoles $/ \mathrm{kg}$. Plasma IRG levels were higher than those in control experiments, but the differences were not significant.

\section{Niludipine}

Changes in blood glucose, plasma IRI and plasma IRG after administration of niludipine are shown in Fig. 2. No remarkable change was observed in blood glucose levels in the femoral artery throughout the experiment when arginine and niludipine were administered. Plasma IRI in the pancreatic vein changed from $121 \pm 15$ to $192 \pm 24 \mu \mathrm{U} / \mathrm{ml}$ and then $114 \pm 14 \mu \mathrm{U} / \mathrm{ml}$ after arginine injection. After administration of 5 nmoles $/ \mathrm{kg}(2.5 \mu \mathrm{g} / \mathrm{kg})$ of niludipine, it decreased to $78 \pm 13 \mu \mathrm{U} /$ 

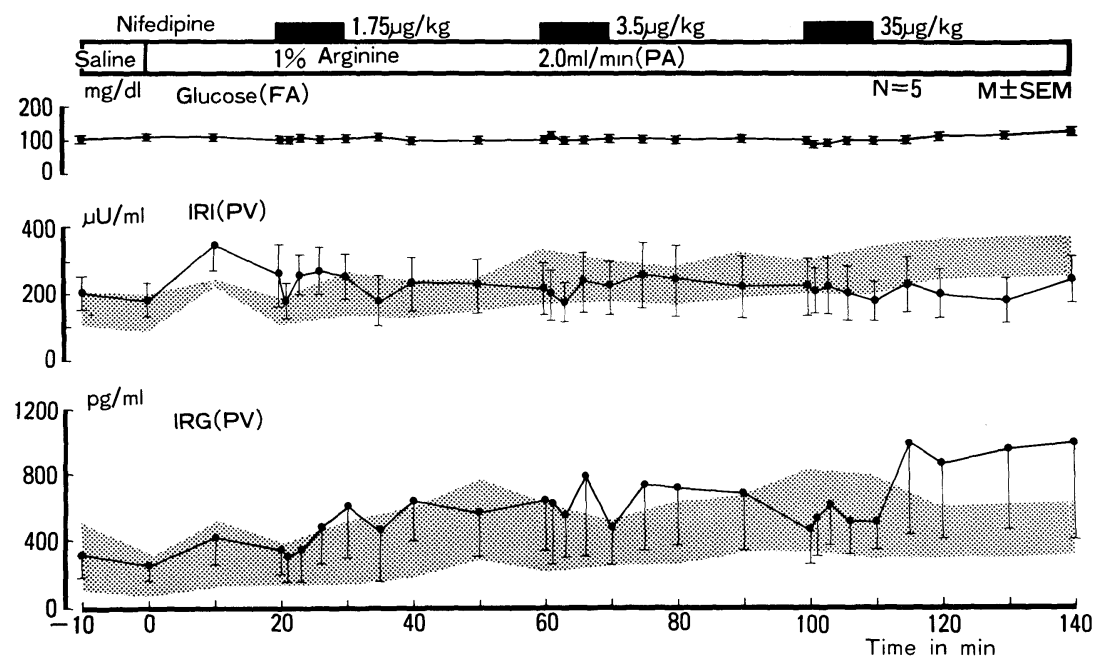

Fig. 1. Effect of intrapancreatic administration of nifedipine on insulin and glucagon secretion in anesthetized dogs. Changes during infusion of argnine alone in a group of five dogs are presented as shaded areas in Figs. 1-3.
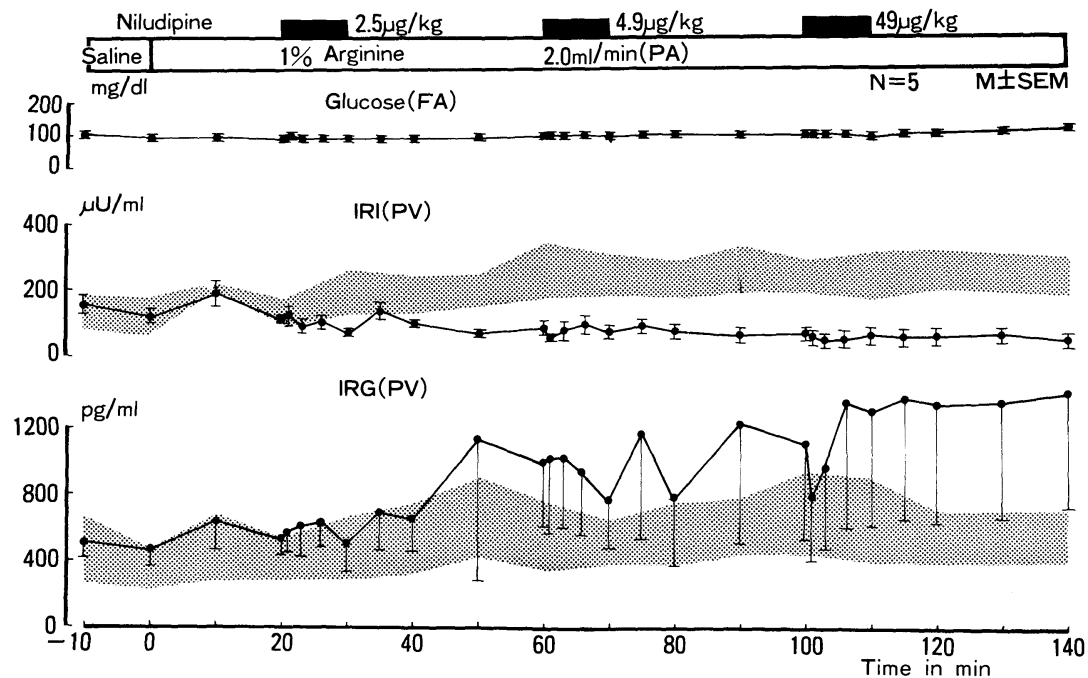

Fig. 2. Effect of intrapancreatic administration of niludipine on insulin and glucagon secretion in anesthetized dogs.

$\mathrm{ml}$; from $98 \pm 24$ to $64 \pm 10 \mu \mathrm{U} / \mathrm{ml}$ in a dose of $10 \mathrm{nmoles} / \mathrm{kg}(4.9 \mu \mathrm{g} / \mathrm{kg})$ and from $87 \pm 17$ to $59 \pm 16 \mu \mathrm{U} / \mathrm{ml}$ in a dose of 100 nmoles $/ \mathrm{kg}(49 \mu \mathrm{g} / \mathrm{kg})$. These changes in plasma IRI were not significant in comparison with preinfusion levels. Although the levels of plasma IRI during the experiment with niludipine seemed to be lower than those in the control experiment, the differences did not reach a statistical significance. Plasma IRG in the pancreatic vein increased from $461 \pm 81$ to $826 \pm$ 
152 and then $528 \pm 81 \mathrm{pg} / \mathrm{ml}$ after the administration of arginine. It increased to $1124 \pm 376 \mathrm{pg} / \mathrm{ml}$ after the administration of niludipine in a dose of $5 \mathrm{nmoles} / \mathrm{kg}$; from $992 \pm 355$ to $1235 \pm 703 \mathrm{pg} / \mathrm{ml}$ with 10 nmoles $/ \mathrm{kg}$; and from $1107 \pm 576$ to $1419 \pm$ $678 \mathrm{pg} / \mathrm{ml}$ with $100 \mathrm{nmoles} / \mathrm{kg}$. However, changes were not significant due to wide deviations. Furthermore, the plasma IRG levels during niludipine administration did not show any significant changes in comparison with arginine. Blood pressure was not markedly influenced by niludipine.

\section{Verapamil}

Changes in blood glucose, plasma IRI and plasma IRG during experiments with verapamil in a group of five dogs are shown in Fig. 3.
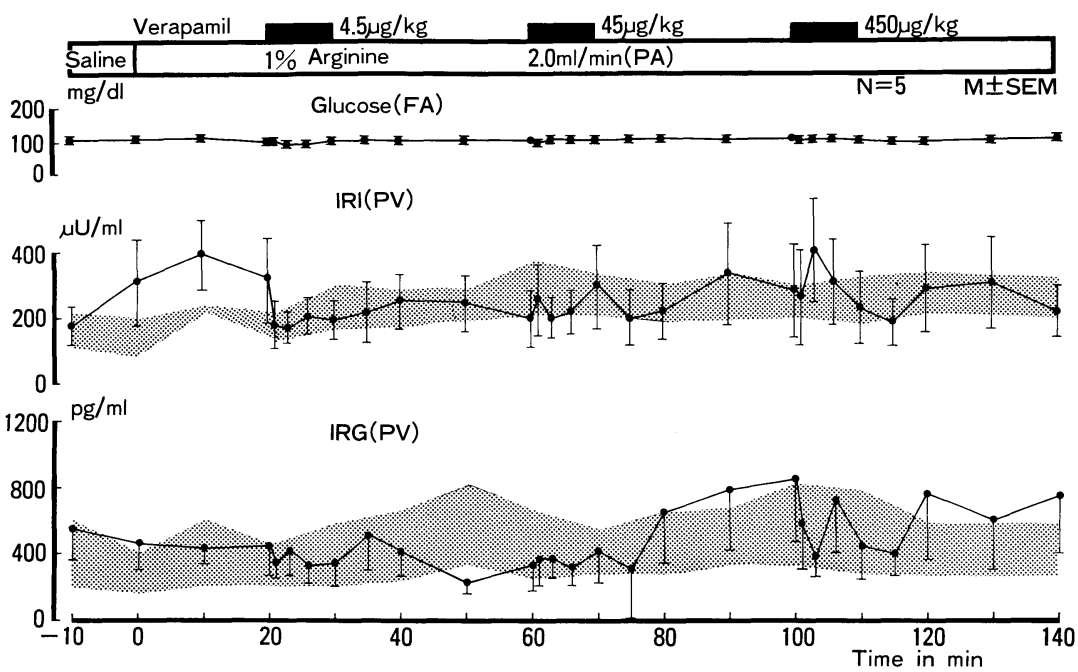

Fig. 3. Effect of intrapancreatic administration of verapamil on insulin and glucagon secretion in anesthetized dogs.

The blood glucose level was $109 \pm 6.7 \mathrm{mg} / 100 \mathrm{ml}$ at the start of the experiment and hardly changed after administration of arginine or verapamil was added. Plasma IRI rose from $320 \pm 130$ to $398 \pm 108$ and up to $328 \pm 135 \mu \mathrm{U} / \mathrm{ml}$ after administration of arginine. Plasma IRI levels fell to $172 \pm 45 \mu \mathrm{U} / \mathrm{ml} 6 \mathrm{~min}$ after administration of verapamil (10 nmoles $/ \mathrm{kg}, 4.5 \mu \mathrm{g} / \mathrm{kg}$ ), but rose to $199 \pm 83$ $\mu \mathrm{U} / \mathrm{ml} 40 \mathrm{~min}$ after verapamil infusion. When verapamil was administered in doses of $100 \mathrm{nmoles} / \mathrm{kg}(45 \mu \mathrm{g} / \mathrm{kg})$ and $1,000 \mathrm{nmoles} / \mathrm{kg}(450 \mu \mathrm{g} / \mathrm{kg})$, plasma IRI decreased slightly to $194 \pm 50$ and $188 \pm 62 \mu \mathrm{U} / \mathrm{ml}$, respectively, but was not significantly different from those in the control experiment with arginine. Plasma IRG was barely changed by verapamil in a dose of 10 or $100 \mathrm{nmoles} / \mathrm{kg}$, but tended to decrease with $1,000 \mathrm{nmoles} / \mathrm{kg}$. 


\section{Comparison of maximal response of plasma IRI and IRG}

To quantify the effect of the test drugs, maximal responses of plasma IRI and IRG in comparison with preinfusion levels were calculated for each group, as shown in Table 1. Plasma IRI decreased, but plasma IRG increased in response to each dose of calcium antagonists in all groups.

TABLE 1. Maximal response of plasma IRI and IRG to three calcium antagonists in three graded doses

\begin{tabular}{cccccc}
\hline Calcium antagonist & $\begin{array}{c}\text { Dosage } \\
(\mathrm{nmoles} / \mathrm{kg})\end{array}$ & \multicolumn{2}{c}{ Insulin response } & \multicolumn{2}{c}{ Glucagon response } \\
& & $(\mu \mathrm{U} / \mathrm{ml})$ & $p$-value & $(\mathrm{pg} / \mathrm{ml})$ & $p$-value \\
\hline Nifedipine & 5 & $-126 \pm 41$ & $<0.05$ & $+297 \pm 184$ & n.s. \\
& 10 & $-58 \pm 32$ & n.s. & $+254 \pm 176$ & n.s. \\
Niludipine & 100 & $-62 \pm 20$ & $<0.05$ & $+381 \pm 184$ & n.s. \\
& 5 & $-63 \pm 19$ & $<0.05$ & $+297 \pm 95$ & $<0.05$ \\
Verapamil & 10 & $-25 \pm 9$ & $<0.05$ & $+462 \pm 282$ & n.s. \\
& 100 & $-40 \pm 6$ & $<0.01$ & $+379 \pm 138$ & $<0.05$ \\
& 10 & $-166 \pm 88$ & n.s. & $+140 \pm 71$ & n.s. \\
& 100 & $-35 \pm 29$ & n.s. & $+331 \pm 176$ & n.s. \\
& 1000 & $-127 \pm 83$ & n.s. & $+192 \pm 75$ & n.s. \\
\hline
\end{tabular}

* Values are means \pm s.e. n.s., not significant.

\section{Discussion}

The interaction between blood calcium levels and insulin secretion from the B cells of Langerhans' islets is well known. Insulin secretion depends on extracellular calcium concentration (Grodsky and Bennet 1966; Curry et al. 1968). Changes of calcium concentration within the $\mathrm{B}$ cells are thought to be largely responsible for glucose-induced insulin secretion (Malaisse-Lagae and Malaisse 1971). Recently it is demonstrated that nifedipine and several chemically related drugs inhibit glucose-induced insulin secretion, together with a lower calcium uptake in isolated rat islets (Malaisse-Lagae and Boschero 1977; Malaisse and Sener 1981).

Presently, there is no concrete explanation of the relationship between calcium concentration and glucagon secretion. We reported that the administration of calcium decreases the secretion of pancreatic glucagon in dogs (Ohneda et al. 1974). However, when other animal species and different experimental methods were used, controversial results were obtained (Kuzuya et al. 1974; Ashby and Speake 1975).

To clarify further the interactions between calcium and pancreatic glucagon secretion, the present experiments were carried out, using nifedipine and niludipine, as well as verapamil as a control drug. In this study, nifedipine and niludipine were administered in a dose of one tenth of that for verapamil, based on the comparative effects of these Ca antagonists on coronary blood flow and myocardial contractility (Himori et al. 1976). Insulin secretion was lowered by either Ca antagonist, but their effect on pancreatic glucagon secretion differed from one test to another. Nifedipine and niludipine clearly enhanced secretion of glucagon, while verapamil was less active in this respect. 
From the results of the present experiments, we concluded that the administration of $\mathrm{Ca}$ antagonists into the pancreatic artery of dogs tended to decrease the secretion of insulin and to increase that of pancreatic glucagon. However, the changes were not statistically significant in comparison with preinfusion levels due to deviations of the plasma hormone levels in the pancreatic vein of individual animals. According to the results obtained elsewhere, a decrease in insulin secretion and an increase in pancreatic glucagon secretion were more pronounced when another Ca antagonist was given together with glucose (Ohneda et al. 1981). In our experiments, however, we used arginine infusion instead. This may be the reason why effects of these drugs on both pancreatic insulin and glucagon secretions were less marked.

Then, what is the mechanism by which Ca antagonists affect the secretion of insulin and glucagon? The following views have been hitherto advanced concerning the relationship between calcium and the secretion of pancreatic glucagon (Leclercq-Meyer et al. 1976, 1979):

(1) A decrease in calcium levels essentially stimulates the secretion of pancreatic glucagon. (2) On the other hand, however, the secretion of pancreatic glucagon is decreased by the permissive action of calcium ion at lower levels of calcium. (3) Under the condition with low calcium levels, the secretion of pancreatic glucagon is not inhibited by glucose but rather increased. Therefore, it is presumable that, when $\mathrm{Ca}$ antagonists are administered, the secretion of pancreatic glucagon is increased by the mechanism under (1), through the inhibition of calcium influx into the A cell.

It seems also likely that the secretion of pancreatic glucagon has been raised by the negative feed back, in which lowered secretion of insulin promotes the secretion of pancreatic glucagon, as mentioned by Samols et al. (1972).

However, the relationship between calcium and the secretion of pancreatic glucagon is so complex that the effects of $\mathrm{Ca}$ antagonists upon the A cells of the pancreas may differ with the experimental conditions.

\section{Acknowledǵment}

This study was supported in part by a Scientific Research Grant (No. 437048) from the Ministry of Education, Science and Culture, Japan.

\section{References}

1) Ashby, J.P. \& Speake, R.N. (1975) Insulin and glucagon secretion from isolated islets of Langerhans. Biochem. J., 150, 89-96.

2) Curry, D.L., Bennet, L.L. \& Grodsky, G.M. (1968) Requirement for calcium ion in insulin secretion by the perfused rat pancreas. Amer. J. Physiol., 214, 174-178.

3) Grodsky, G.M. \& Bennet, L.L. (1966) Cation requirement for insulin secretion in the isolated perfused pancreas. Diabetes, 15, 910-913.

4) Himori, N., Ohno, H. \& Taira, N. (1976) Simultaneous assessment of effects of coronary blood flow and the myocardial contractility by using the blood-perfused canine papillary muscle. Jap. J. Pharmacol., 26, 427-435.

5) Iversen, J. \& Hermansen, K. (1977) Calcium, glucose and glucagon release. Diabetologia, 13, 297-303. 
6) Kuzuya, K., Kajinuma, H. \& Ide, T. (1974) Effect of intrapancreatic injection of potassium and calcium on insulin and glucagon secretion in dogs. Diabetes, 23, 55-60.

7) Leclercq-Meyer, V., Marchand, J. \& Malaisse, W.J. (1973) The effect of calcium and magnesium on glucagon secretion. Endocrinology, 93, 1360-1370.

8) Leclercq-Meyer, V., Marchand, J. \& Malaisse, W.J. (1976) The role of calcium in glucagon release interactions between glucose and calcium. Diabetologia, 12, 531-538.

9) Leclercq-Meyer, V., Marchand, J. \& Malaisse, W.J. (1979) Calcium dependency of glucagon release: its modulation by nutritional factors. Amer. J. Physiol., 236, E98-E104.

10) Malaisse-Lagae, F. \& Boschero, A.C. (1977) Calcium antagonists and islet function. XI. Effect of nifedipine. Hormone Res., 8, 203-209.

11) Malaisse-Lagae, F. \& Malaisse, W.J. (1971) Stimulus-secretion coupling of glucoseinduced insulin release. III. Uptake of ${ }^{45}$ Calcium by isolated islets of Langerhans. Endocrinology, 88, 72-80.

12) Malaisse, W.J. \& Sener, A. (1981) Calcium-antagonists and islet function. XII. Comparison between nifedipine and chemically related drugs. Biochem. Pharmacol., 30, 1039-1041.

13) Morgan, C.R. \& Lazarow, A. (1963) Immunoassay of insulin: two antibody system. Plasma insulin levels of normal, subdiabetic and diabetic rats. Diabetes, 12, 115-126.

14) Ohneda, A., Matsuda, K., Horigome, K., Ishii, S. \& Yamagata, S. (1974) Effect of intrapancreatic administration of calcium upon glucagon secretion in dogs. Tohoku J. exp. Med., 113, 301-311.

15) Ohneda, A., Ishii, S., Horigome, K. \& Yamagata, S. (1975) Glucagon response to arginine after treatment of diabetes mellitus. Diabetes, 24, 811-819.

16) Ohneda, A., Ishii, S., Horigome, K., Chiba, M., Sakai, T., Kai, Y., Watanabe, K. \& Yamagata, S. (1977) Effect of intrapancreatic administration of vasoactive intestinal peptide upon the release of insulin and glucagon in dogs. Horm. Met. Res., 9, 447-452.

17) Ohneda, A., Kobayashi, T. \& Nihei, J. (1981) Effect of the calcium antagonist diltiazem upon secretion of pancreatic and extrapancreatic glucagon in dogs. Biomed. Res., 2, 119-125.

18) Rubin, R.P. (1970) The role of calcium in the release of neurotransmitter substances and hormones. Pharmacol. Rev., 22, 389-428.

19) Samols, E., Tyler, J.M. \& Marks, V. (1972) Glucagon-insulin interrelationships. In: Glucagon, edited by P.J. Lefebvre \& R.H. Unger, Pergamon Press, Oxford-New York, pp. 151-173.

20) Teller, J.D. (1956) Direct, quantitative, colorimetric determination of serum or plasma glucose. In: Abstracts, the 130th Meeting, Amer. Chem. Soc., Sept., p. 69c. 